\title{
THE GROWTH OF KIWI SHOOT (ACTINIDIA DELICIOSA) ON VARIOUS KINDS OF GELLING AGENTS
}

\author{
Mardiana $^{(1)}$, Zainuddin $^{(1)}$, Mahfudz $^{1)}$, Hawalina $^{(1)}$ \\ ${ }^{1)}$ Study Program of Agrotechnology Faculty of Agriculture, Tadulako University, Palu \\ Email: mardianajalaluddin66@gmail.com,Zainuddin.untad@gmail.com, mahfudzuntd62@gmail.com, \\ hawalinak@yahoo.com
}

\begin{abstract}
Kiwi fruit takes about 25 weeks from flower bloom until it reaches physiological maturity, so the time required to produce kiwi seeds from seeds in large quantities and uniform is very long. Tissue culture is one method that can be used to obtain a lot of kiwi seeds and uniforms with large quantities in a faster time. The purpose of this study was to examine various types of media compaction materials for the growth of kiwi shoots in vitro. This study was prepared based on Completely Randomized Design (RAL) with 5 treatments and repeated 4 times so that there were 20 experimental units, each experiment using 2 explants so that there are 40 eksplan. The treatments were: MA 1: Agar Swallow Globe $8 \mathrm{~g} / 1$, MA 2: Agar Swallow Globe $4 \mathrm{~g} / 1+$ Agar Nutrijell 4 g / 1, MA 3: Agar Swallow Globe 4 g / 1 + Agar Nutrijell 5 g / 1, MA 4: Phytagel 2.2 g / 1, MA 5: Agar Nutrijell $11 \mathrm{~g} / 1$. Observation variables are When shoots appear, Number of shoots, number of leaves, Number of Roots, number of root hair. The results showed Swallow Globe $4 \mathrm{~g} / \mathrm{l}$ + Agar Nutrijell $4 \mathrm{~g} / \mathrm{l}$ treatment gave the highest average number of shoots, the highest number of leaves and roots, this proved that the combination of Swallow Globe and Nutrijell agar gave a good condition for shoot growth kiwi plant.
\end{abstract}

Keywords : Gelling Agents, Growth, Kiwi Shoot.

\section{INTRODUCTION}

In Indonesia, kiwi is known as imported fruit, which is only found in supermarket at quite expensive price. The price of kiwi fruit in Palu City range from Rp 70,000 to Rp 110,000 / kg (June-August 2017 Survey). The high level of consumer interest and unsustainable supply is a challenge as well as a good opportunity for the development of this commodity.

Kiwi fruit has excotic color and meat with the content of several dominant elements per 100 grams of fresh fruit. There are $64 \mathrm{mg} \mathrm{P,} 30 \mathrm{mg} \mathrm{Mg}, 16 \mathrm{mg} \mathrm{Ca}, 105 \mathrm{mg}$ ascorbic acid, 175 I.U. vitamin A, $17.5 \mathrm{~g}$ carbohydrates, $0.79 \mathrm{~g}$ protein, $0.51 \mathrm{mg}$ Fe, $0.50 \mathrm{mg}$ niacin, $0.07 \mathrm{~g}$ fat, $0.05 \mathrm{mg}$ riboflavin, $0.02 \mathrm{mg}$ thiamin and $81.2 \mathrm{~g}$ water, with 66 calories (Morton et al., 1987 in Nanher, 2015). According to Inggrid and Santoso (2014), kiwi fruit has higher antioxidant activity and phenolic content than strawberries, guava, papaya and starfruit.

As a commodity that can be planted in various types of soil and requires altitude between 1000-2500 meters above sea level (m asl) (Sherpa, 2013), kiwi has the opportunity to be cultivated in several altitude areas in Central Sulawesi such as the Napu Plateau (1000-2500 m above sea level ) (Purwaningsih and Yusuf 2005).

Despite having high economic value and suitability of places to be cultivated in several regions in Central Sulawesi, the development is constrained by the unavailability of seed sources. The available opportunity is to multiply the quality of the origin of the fruit plants obtained from supermarkets and to get a large number of healthy seeds, multiplication through tissue culture is the right alternative. Through tissue culture technique can be obtained 
seeds that are free of disease pest with a greater number in a relatively shorter time (Basri, 2004 and Zulkarnain, 2009).

One aspect that determines the successful implementation of tissue culture with solid media is the selection of appropriate media compactor materials. Some types of media compactors commonly used with high quality, there are agar, bacto agar, agarose, gellan gum and gelrite (George et al., 2008). However, the price and the process of procuring high quality compacting materials such as phytagel (one of the gellun gum) is difficult to reach, so the use of alternative media compactors is important.

Several types of alternative media compactor materials have been evaluated for their use in the multiplication of kiwi shoots (Kasim, 2012). The results of the study showrf that the use of the Swallow Globe, Nutrijell plain flavor and the combination of both is potentially good for growing kiwi shoot as well as phytagel but the concentration used still needs to be evaluated. Based on the description above, it is necessary to conduct research to get the right type of media compactor material.

This study aimed to examine various types of media compactors for the growth of kiwi shoots in vitro.

\section{RESEARCH METHOD}

This research was conducted at Plant Biotechnology Laboratory, Faculty of Agriculture, Tadulako University, Palu. It was conducted from January to May 2018.

The tools used in this research were beaker, measuring cup, pipette, petri dish, culture bottle, tweezers, scalpe, stirring rod, SA 300 VA microm series autoclaves, 100800 modell oven, $\mathrm{pH}$ meter, laminar air flow cabinet / Bio safety cabinet model JBSCV, analytical scale AR1140 / C, hand sprayer, Bunsen burner, hot plate cimarec 2, magnetic stirrer, shaker, refrigerator, plastic, aluminum foil, rubber band, funnel, filter paper, label paper, rack culture, and micro pipette.
The ingredients used were $70 \%$ alcohol, spritus, MS media, so that Swallow Globe, Nutrijell, phytagel, tissue, detergent, chlorox, sterile distilled water, $1 \mathrm{~N} \mathrm{HCl}$, $1 \mathrm{~N} \mathrm{NaOH}, \mathrm{BAP}, \mathrm{NAA}$, and kiwi shoot explants obtained from sterile kiwi sprout.

This study was prepared based on a Completely Randomized Design (CRD) with 5 treatments and repeated 4 times so that there were 20 experimental units, each experiment using 2 explants so that there were 40 explants. The treatment was: MA1: so that Swallow Globe is $8 \mathrm{~g} / 1$, MA 2: Swallow Globe was $4 \mathrm{~g} / 1+$ for Nutrijell 4 g / 1, MA 31 Swallow Globe $4 \mathrm{~g} / 1+$ Nutrijell 5 g / 1, MA 4: Phytagel 2.2 g / 1, MA 5: Nutrijell was $11 \mathrm{~g} / \mathrm{l}$. Observation variables were analyzed by analysis of variance (ANOVA), if it had a significant effect, further testing was carried out using the Honestly Significant Difference (BNJ) with level of $5 \%$, in order to find out the difference in the mean value of the treatment tested.

\section{RESULTS AND DISCUSSION}

When The Shoot Appears. Observation data when shhot appeared on various types of media compactor material showed that the treatment of various types of media compactor gave a very real influence on the appearance of the kiwi plant shoot The average when shoot appear was presented in Table 1.

Table 1. When HST Shoot Appeared.

\begin{tabular}{cc}
\hline Treatment & Average \\
\hline MA 1 & $7.25^{\mathrm{a}}$ \\
MA 2 & $8.50^{\mathrm{a}}$ \\
MA 3 & $7.13^{\mathrm{a}}$ \\
MA 4 & $8.38^{\mathrm{a}}$ \\
MA 5 & $10.75^{\mathrm{b}}$ \\
\hline BNJ 5 \% & 2.52 \\
\hline \multirow{2}{*}{ Description : The Numbers Followed by Same } \\
\multicolumn{2}{c}{ Letters, Not Different At BNJ } \\
\multicolumn{2}{c}{ 5\% Test Level }
\end{tabular}


Table 2. The Average Number of Shoot at 4, 6 dan 8 MST.

\begin{tabular}{cccc}
\hline Treatment & 4 MST & 6 MST & 8 MST \\
\hline MA 1 & $2.50^{\mathrm{a}}$ & $4.13^{\mathrm{ab}}$ & $4.62^{\mathrm{a}}$ \\
MA 2 & $3.38^{\mathrm{a}}$ & $7.13^{\mathrm{c}}$ & $9.37^{\mathrm{c}}$ \\
MA 3 & $2.38^{\mathrm{a}}$ & $5^{\mathrm{b}}$ & $7.75^{\mathrm{b}}$ \\
MA 4 & $2.13^{\mathrm{a}}$ & $3^{\mathrm{a}}$ & $4.50^{\mathrm{a}}$ \\
MA 5 & $2.50^{\mathrm{b}}$ & $5.75^{\mathrm{bc}}$ & $8.50^{\mathrm{bc}}$ \\
\hline BNJ 5 \% & 0.69 & 1.93 & 2.80 \\
\hline
\end{tabular}

Description : The numbers followed by same letters, not different at BNJ 5\% test level.

Table 3. The Average Number of Leaves at 8 Th Week.

\begin{tabular}{cc}
\hline Treatment & Average \\
\hline MA 1 & $4.12^{\mathrm{a}}$ \\
MA 2 & $8.62^{\mathrm{c}}$ \\
MA 3 & $4.25^{\mathrm{a}}$ \\
MA 4 & $5.62^{\mathrm{ab}}$ \\
MA 5 & $7.50^{\mathrm{bc}}$ \\
\hline BNJ 5 $\%$ & 3.27 \\
\hline
\end{tabular}

Description : The numbers followed by same letters, not different at BNJ 5\% test level.

BNJ test results at the level of $5 \%$ indicates that the MA treatment is 3 (Swallow Globe $4 \mathrm{~g} / 1$ Agar + Nutrijell $5 \mathrm{~g}$ / 1 Agar) produces the average value when the fastest shoots appear and are not significantly different from other treatments except, MA 5 treatment (Nutrijell $11 \mathrm{~g} / 1$ Agar).

The number of shoots. Data on the number of shoots observed at 4 th , 6 th , and 8 th MST week on the administration of various types of media compactors, it showed that the treatment of various types of media compactors gave a very significant effect on the number of buds of kiwi plant, the average number of shoots was presented in Table 2.

BNJ test results at the level of $5 \%$ indicate that on the 4th week the MA treatment is 2 (Swallow Globe $4 \mathrm{~g}$ agar / 1 + Nutrijell $4 \mathrm{~g} / 1$ agar) produces the highest average number of shoots and is significantly different from the other treatments. Where as at the 6th and 8th week obtained MA 2 treatment produced the highest average number of shoots and significantly different from other treatments except, MA 5 treatment (Nutrijell agar $11 \mathrm{~g} / 1$ ).

Observation data of leaf number showed that the treatment of media compactors at 4 th and 6 th week did not have a significant effect but, at 8 th week obtained a very real effect. The average number of leaves from various treatments at 8 th weekcan be seen in Table 3 .

BNJ test results at 5\% level indicated that the MA treatment was 2 (Swallow Globe $4 \mathrm{~g} / 1$ agar + Nutrijell 4 $\mathrm{g} / \mathrm{l}$ agar) produced the highest average number of leaves and was significantly different from other treatments except MA 5 treatment ( Nutrijell order $11 \mathrm{~g} / 1$ ).

The Number of Roots. Observation data showed that the treatment of various types of media compactor obtained a very real influence on the number of roots of kiwi plant. The average number of roots as presented in Table 4. 
Table 4. The Average Number of Roots at 8 th week

\begin{tabular}{cc}
\hline Treatment & Average \\
\hline MA 1 & $10.63^{\mathrm{c}}$ \\
MA 2 & $9.25^{\mathrm{bc}}$ \\
MA 3 & $3.50^{\mathrm{a}}$ \\
MA 4 & $5.63^{\mathrm{a}}$ \\
MA 5 & $6^{\mathrm{ab}}$ \\
\hline BNJ 5 \% & 3.27 \\
\hline
\end{tabular}

Description : The numbers followed by same letters, not different at BNJ 5\% test level.

Table 5. The Number of Root hairs at 8 th Week.

\begin{tabular}{cc}
\hline Treatment & Average \\
\hline MA 1 & $9.50^{\mathrm{cd}}$ \\
MA 2 & $10.50^{\mathrm{d}}$ \\
MA 3 & $1.88^{\mathrm{a}}$ \\
MA 4 & $6.88^{\mathrm{bc}}$ \\
MA 5 & $3.88^{\mathrm{ab}}$ \\
\hline BNJ 5 \% & 3.06 \\
\hline
\end{tabular}

Description : the numbers followed by same letters, not different at BNJ 5\% test level.

BNJ test results at the level of $5 \%$ indicated that the MA treatment was 1 (so that the Swallow Globe $8 \mathrm{~g} / \mathrm{l}$ ) produced the highest average number of roots and was significantly different from other treatments except MA treatment 2 (Swallow Globe 4/ 1 agar + Nutrijell agar $4 \mathrm{~g} / 1$ agar)

The Number of root hairs. Observation data showed that the treatment of various types of media compactor obtained a very significant effect on the number of roots of kiwi plants.

BNJ test results at the level of $5 \%$ indicated that the MA treatment was 2 (Swallow Globe $4 \mathrm{~g} / 1+$ Nutrijell $4 \mathrm{~g} / \mathrm{l}$ agar) at 8th week, it produced the average number of the root hair and significantly different from other treatment except the MA 1 treatment (Swallow Globe $8 \mathrm{~g} / 1$ agar). The results showed that when the shoots appear faster in the treatment of Swallow Globe is $4 \mathrm{~g} / \mathrm{l}$ agar + Nutrijell agar $5 \mathrm{~g} / \mathrm{l}$ agar, this treatment obtained a poor response to the number of shoots, number of leaves, number of roots and number of root hairs. Whereas in the treatment of Swallow Globe 4 g / 1 agar + so Nutrijell $4 \mathrm{~g} / \mathrm{l}$ agar obtained the highest average number of shoots, number of leaves and number of root hairs, this proved that at the right concentration the combination for Globe and Nutrijell Swallows was really good for Kiwi plant growing.

The combination of Swallow Globe $4 \mathrm{~g} / \mathrm{l}$ agar + Nutrijell $4 \mathrm{~g} / \mathrm{l}$ agar) produced a gel that is able to support the establishment of explants and can make explants absorb nutrients properly while in the treatment of Swallow Globe $4 \mathrm{~g} / 1$ agar + Nutrijell $5 \mathrm{~g} / 1$ agar it produced gel which was able to support the establishment of explants but the diffusion of water and nutrients to explants decreased which causes explant growth to be disrupted. This is because at high concentration the gel became so hard and the water and the nutrients that diffused into the plant became disrupted.

Taji et al., (1997) stated that at high gel concentration causing the gel become hard so that the amount of available water and nutrients which diffuse into the plant becomes disturbed. Kasim (2012) stated that the gel structure given so that Nutrijell was strong enough to support the plant and the need for nutrient in the media can be supplied through the movement of nutrients (chemicals) from the media used. Scholten and Pierik (1997) stated that Murashige and skoog salts became immobile up to $30 \%$ in the gel-added medium. The right concentration can cause good contact between explants and the media and facilitate nutrient absorption (Hartmann et al., 1990).

The function of compacting material in general is to increase the viscosity of the media so that the tissue or organ of the plant can remain above the media surface (Prakash et al., 2004). The content of kojak flour (konnyaku) and keragenan contained in Nutrijell and agar flour contained in the Swallow Globe can increase the strength 
and elasticity of the gel. Tako and Nakamura, (1988); Goycoolea (1995) said that the addition of kojac in agar gel and kappa keragenan can increase the strength and elasticity of the gel.

The rapid appearance of shoots was suposed due to the high $\mathrm{Ca}$ content in the combination of Swallow Globe $4 \mathrm{~g} / 1$ agar + Nutrijell r 5 g / 1 agar. According to Suprihatin (2011) calcium $(\mathrm{Ca})$ is the main element needed for growth and proper function of the root tips. Compactor gel contains a number of minerals that can affect plant growth, where the resulting gel matrix can bind or adsorb minerals such as calcium, iron, and zinc (Basri 2004).

The appearance of new shoots is one of the growth processes in explants. According to Hidayat (1995), growth is an increase in cell numbers, tissue weight and other factors that make an explant live an intact individual. The addition of phytagel $2.2 \mathrm{~g} / \mathrm{l}$ gave a good number of leaves, number of roots, and number of root hair. This proves that the matrix gel produced by phytagel $2.2 \mathrm{~g} / \mathrm{l}$ was good enough to sustain the growth of kiwi shoots. In contrast to Kasim's (2012) study, the addition of phytagel $2.2 \mathrm{~g} / \mathrm{l}$ gave the highest number of leaves, buds and segments but did not produce roots.

The treatment for Swallow Globe 8 $\mathrm{g} / \mathrm{l}$, at 8 th week gave more roots than other treatments, but the average number of shoots and leaves was lower than Kasim (2012). In Kasim's research (2012) treatment for Swallow Globe $8 \mathrm{~g} / 1$, at 8 th weekdid not show any sign of root appearance, but the average number of leaves and shoots was more. This is thought to occur because in Kasim's (2012) study, the process of germination of kiwi seeds using MS 1 (full) media while in this study the medium of kiwi germination used was MS $1 / 2$ medium.

According to Syafarudin et al. (2010), the concentration of MS 1/2 medium explant appears to produce lower shoot growth and tends to form roots. This condition is also shown in rose culture conducted by Marlina (2004), where in media concentrations of less than $100 \%$ MS produced the size and number of roots continue to increase but the size and number of shoots continue to decrease.

Yuniyati (2005) stated that rooting can occur in full concentrated MS media, but the effect of media on rooting would be better if the MS media used is only half of the concentration. According to Yusnita, (2010) in Latifah et al, (2017). MS $1 / 2$ media proved to be better than the media with MS and micro macro nutrient concentrations $1 / 4$ and MS 1 (full). Saputri's research (2005) in Syafarudin et al. (2010) showed that at the concentration of $1 / 2$ MS media it was able to produce the highest number of roots in onion shoots, while the concentration of 1 MS media produced the lowest number of roots.

Islam et al., (2003) stated that MS $1 / 2$ can support rapidly producing orchid protocorms, because it contain high ions and nutrients. The use of MS $1 / 2$ media both used as a basic media because MS 1/2 media contains macro and micro nutrients such cobalt $(\mathrm{Co})$, copper $(\mathrm{Cu})$, zinc $(\mathrm{Zn})$, boron (B), and molybdenum (Mo) which are not found in Knudson media. $\mathrm{C}$ and Vacin Went. MS $1 / 2$ media also contains a fairly large amount of myoino-sitol (100 mg / L) (Yusnita, 2004).

In tissue culture, the number of roots indicates that the plantlet is health and able to absorb nutrients in the media optimally. The number of roots in plant indicates how wide the plant is in absorbing nutrients and nutrients. The more number of roots the wider the range of plants and the more nutrients and absorbed nutrients (Latifah et al, 2017).

\section{CONCLUSION AND SUGGESTION}

\section{Conclusion}

Based on the results of the study, it can be concluded that the treatment for Swallow Globe $4 \mathrm{~g} / 1+$ for Nutrijell $4 \mathrm{~g} / \mathrm{l}$ obtained the highest average number of shoots, number of leaves and root hairs, this 
proves that the Globe and Nutrijell Swallow combination at the proper and significant concentration, it provides good condition for the growth of the kiwi plant shoots.

\section{Suggestion}

Based on the results of this study it is recommended to use the Swallow Globe Agar $4 \mathrm{~g} / 1+$ Nutrijell agar $4 \mathrm{~g} / \mathrm{l}$ as a medium compacting agent for the growth of kiwi shoot.

\section{REFERENCES}

Basri, Z. 2004. Kultur Jaringan Tanaman. Universitas. Tadulako. Palu.

George, E. F.., M.A. Hall, dan Geert-Jan De Klerk. 2008. Plant Propagation by Tissue Culture. 3rd Edition Volume 1. The Background. Springer Publihser. Dordrecht, Netherlands. 501 p.

Goycoolea FM, Richardson RK, Morris ER, Gidley MJ. 1995. Effect of locust bean gum and konjac glucomannan on the conformation and rheology of agarose and $k$ - carrageenan. $\mathrm{J}$ Biopolymers $36: 643-658$.

Gunawan, L. W dan Wiendi W. M. A. 1992. Pengaruh Subkultur Beruntun dan Media Tumbuh In Vivo Terhadap Keberhasilan Aklimatisasi Bibit Rotan Hasil Perbanyakan In Vitro. Jurnal Ilmu Pertanian Indonesia. 2(2):74-81.

Hartmann, H.T., D.E. Kester, and F.T. Davies. 1990. Plant Propagation: Principles and Practices. 5th ed. Singapore: Prentice Hall Inc.

Hidayat E.B. 1995. Anatomi Tumbuhan Berbiji. Bandung: Penerbit ITB.

Inggrid, M dan H. Santoso, 2014. Ekstraksi Antioksidan dan senyawa Aktif dan Buah kiwi (Actinidia delisiosa). Lembaga Penelitian dan Pengabdian Kepada masyarakat. Universitas Katolik Parahyangan.

Islam, M.O., A.R.M.M. Rahman, S. Matsui, and A.K.M.A. Prodhan. 2003. Effects of Complex Organic Extracts on Callus Growth and PLB Regeneration Through Embryogenesis in the Doritaenopsis Orchid. Japan Agricultural Research Quarterly: JARQ, 37(4). pp.229-235.

Kasim. H, 2012. Pertumbuhan Tunas Kiwi (Actinidia delisiosa) Pada Berbagai Bahan pemadat Media Secara In Vitro. Media Litbang sulteng V(1): 42-47.

Latifah R, T. Suhermiatin dan N. Ermawati. 2017. Optimization Of The Growth Cattleya Plantlet Through Strength Combination Of Murashige-Skoog And Organic Substances. Agriprima, Journal of Applied Agricultural Sciences. Vol. 1, No. 1, Hal. 59-68.

Marlina, N. 2004. Teknik Modifikasi Media Murashige dan Skoog (MS) untuk Konservasi In Vitro Mawar (Rossa spp.). Buletin Teknik Pertanian. 9(1):4-6.

Nairn, B.J., R.H. Furneaux and T.T. Stevenson, (1995). Identification of an agar constituent responsible for hydric control in micropropagation of radiata pine. Plant Cell Tissue Organ Culture. 43, 1-11.

Nanher T. S.A.H., S. Sahay, V. Kumar, B. Kanchan, N. Kumar and M. Ahmad. 2015. Kiwifruit health benefits and medicinal importance. Rashtiya krishi. Vol 10 (2).

Prakash, S., M.I. Hoque, dan T. Brinks. 2004. Culture Media and Containers. Proceedings of a Technical Meeting organized by the Hoint FAO/IAEA Division of Nuclear Techniques in Food and Agriculture and held in Vienna. 26-30 August 2002. 106: 29 — 40. 
Purwaningsih dan R. Yusuf. 2005. Komposisi Jenis Dan Struktur Vegetasi Hutan Dikawasan Pakuli, Taman Nasional Lore Lindu, Sulawesi Tengah. Biodiversitas. Vol 6. No 2 : 123 128.

Scholten, H.J. and R.L.M. Pierik, 1997. Agar as a gelling agent: chemical and physical analysis. Biomedical and Life Sciences Plant Cell Reports. Vol. 17 No. 3.

Sherpha, S. 2013. Kiwifruit Cultivation. Natural Resource Management Approachen And Technologies In Nepal. Wocat Database.

Suprihatin (2011). Proses pembuatan pupuk cair dari batang pohon pisang. Jurnal Teknik Kimia , $5(2), 429-433$

Syafarudin, U. Widyastuti, ED Mustikarini dan Y1. Rosa. 2010. Pertumbuhan Tunas Nenas Lokal Bangka Secara In-Vitro Pada Media Murashige-Skoog Dengan Penambahan Thidiazuron. Enviagro, Jurnal Pertanian dan Lingkungan. Vol. 3 No. 1.

Taji, A. M., W. A. Dodd dan R. R. Williams. 1997. Plant Tissue Culture Practice. University of New England, Armidale.

Tako M dan S. Nakamura. 1988. Synergistic interaction between agarose and D-galacto-Dmannan in aqueous media. J Agricultural and Biological Chemistry 52 : 1071-1072.

Yuniyati N. 2005. Pengaruh Konsentrasi Media MS dan NAA Terhadap Pengakaran Alocasia suhirmaniana Secara In Vitro. [Skripsi]. Bogor: Fakultas Pertanian. Institut Pertanian Bogor.

Yusnita. 2004. Kultur Jaringan. Cara Memperbanyak Tanaman Secara Efisien. Jakarta: Agromedia Pustaka.

Zulkarnain. 2009. Kultur Jaringan Tanaman . PT Bumi Aksara. Jakarta. 